\title{
Foam Separation of Microbial Cells
}

\author{
S. Parthasarathy, T.R. Das, and R. Kumar* \\ Department of Chemical Engineering, Indian Institute of Science, \\ Bangalore-560 012, India
}

\author{
K.S. Gopalakrishnan \\ Microbiology and Cell Biology Laboratory, Indian Institute of Science, \\ Bangalore-560 012, India
}

Accepted for publication July 9, 1987

\begin{abstract}
Batch foam separation has been employed to separate Saccharomyces carlsbergensis cells from their broth without the use of any external surface-active agent. A model has been developed to predict the foamate cell concentration as well as the variation of cell concentration in the bulk liquid in the foam column as a function of time. The model assumes a linear equilibrium relation between the cell concentrations at the interface and the bulk. The foam has interface as well as interstitial liquid. The interface is assumed to be in equilibrium with the interstitial liquid, which in turn is assumed to have the same concentration as the bulk. The interfacial area is calculated by assuming the foam bubbles to be pentagonal dodecahedral in shape. The model has been found to explain the results of foam separation of cells quite well, particularly with respect to the effect of bubble size and aeration rate.
\end{abstract}

\section{INTRODUCTION}

Separation of microbial cells from the media is an important industrial operation. As centrifugation, a widely adopted technique for this purpose, requires large energy input per unit mass of the cells separated, many attempts have been made to develop energy-saving separation methods. Flocculation-cum-sedimentation and microflotation, ${ }^{1}$ e.g., employ surface-active agents to obtain separation. However, the surface-active agents reduce the cells' activity, and the separated cells cannot be reused. Therefore, methods employing surfactants can be used only in operations such as sewage treatment, where the reuse of the cells is not required.

Foam separation is already a known method of separating components of a solution by utilizing the differences in their surface activities. This can also be used to separate surface-active cells, which have a tendency to get concentrated at the gas-liquid interface ${ }^{2}$ without the aid of surfactants. Foam separation is particularly suited because foams have large interfacial area per unit volume of the liquid.

Dognan and Dumonte ${ }^{3}$ were the first to separate cells from a solution containing casein hydrolysate by foam flotation without using any surface-active agents. Boyles and

\footnotetext{
* To whom all correspondence should be addressed.
}

Lincoln ${ }^{4}$ separated many species of microorganisms from solutions without any floatation aids and concluded that cells with hydrophobic surfaces separated better and that larger bubbles, which are drier, aided spores' removal whereas smaller bubbles aided removal of vegetative cells. Kalyuzhnyl et al. ${ }^{5}$ concluded that hydrophobicity determines separation of cells and that age of cells also affects separation. They also concluded that the cultivation conditions also influence flotability by changing the hydrophobic nature of the surface of the cells. Levin et al. ${ }^{6}$ reported increased separation with low aeration rate and smaller bubbles.

Recently, Desmaison and Schügerl ${ }^{7}$ separated Hansenula polymorpha from the media in a batch foam column using the natural surface activity of the microorganism. They found that the cell separation and the foamate cell concentration decreased with increase in bulk cell concentration but the separated cell fraction increased. Viehweg and Schügerl ${ }^{8}$ separated the same microorganism in a continuous foam column. They obtained higher separation factors when compared to the ones obtained in batch operation under similar operating conditions. They observed that factors that increase foaminess decrease the foamate cell concentration because of higher liquid holdup. They also found that the bubble size does not have any significant influence on separation and that temperature also barely has any effect on it. Further, they investigated the effect of salts, dilution of the media, and age of the cells on separation. They observed that the higher the age of the cells, the lower the fraction of cells in the foam section. They concluded that the results obtained could not be explained by a mathematical model because of the complex interrelations among various parameters.

The present investigation attempts to develop a preliminary model for cell separation in a batch foam column and verify it against experimental information obtained for the separation of Saccharomyces carlsbergensis.

\section{MODEL DEVELOPMENT}

Foam separation of microbial cells from the broth is based on their preferential accumulation at the gas-liquid inter- 
face. The surface-active cells with hydrophobic surfaces exhibit excess concentration at the surface over that in the bulk.

When a gas is sparged through a pool of broth, the cells with hydrophobic surfaces preferentially attach themselves to the gas-liquid interface. When the bubbles reach the surface of the bulk liquid, they undergo a change in shape from spherical to predominantly pentagonal dodecahedral and become a part of foam. The foam has a high interfacial area associated with a small quantity of liquid. The liquid between the foam bubbles gets distributed between films and Plateau borders (PBs). Each liquid film is surrounded by a limited amount of gas. The meeting of three films forms a PB. Thus, throughout the foam section, there is a network of PBs. There is a flow of liquid from the films to the PBs because of the higher pressure in the liquid films than in the PBs caused by the differences in curvatures. The liquid drains downward, through the network of PBs, to the liquid pool due to gravity. As the foam bubbles move up the column, the amount of liquid associated with them drops sharply near the liquid-foam interface and then reduces very slowly. Because of this drainage, the liquid holdup of foam is very small when it comes out of the column. This is advantageous for cell separation as a very large rate of output of surface area is obtained associated with a very small rate of liquid output. Hence, the concentration of the cells in the outcoming foam is much higher when compared to that in the bulk liquid taken.

An idealized foam-bed cell separation is shown in Figure 1. The foam column is divided into two sections, the storage section and the foam section. The storage section contains the culture broth with microbial cells. The gas bubbles are generated through a gas distributor at the base of the storage section. It is assumed that if the time of contact between the bubbles and the broth is high, equilibrium between the bulk and the interface concentration is achieved. This assumption has actually been verified experimentally. In the present model, we assume that enough contact time is provided to the bubbles in the bulk to attain equilibrium. Thus, no cell exchange between the interface and the interstitial liquid occurs as the foam rises. The bulk is assumed to be well mixed because of the recirculation caused by the swarm of bubbles passing through it.

The following linear relationship has been assumed to hold between the surface concentration and the bulk concentration:

$$
C_{i}^{\prime}=K \cdot C_{B}
$$

where $C_{i}^{\prime}$ pertains to the concentration at the interface expressed as mass of cells per unit volume. The volume associated with unit area of interface is equal to the cell thickness $\delta$ as one end of the cell is attached to the interface. Thus, if the value of $K$ is unity, no separation by this technique can be expected.

As both $K$ and $\delta$ are unknown, it is convenient to define interfacial concentration as mass of cells associated with unit surface area. This can be done by multiplying both sides of equation (1) by $\delta$. Thus, we obtain

$$
C_{i}=\lambda \cdot C_{B}
$$

where

$$
C_{i}=C_{i}^{\prime} \cdot \delta \text { and } \lambda=K \cdot \delta .
$$

The parameter $\lambda$, which clubs the effects associated with both $K$ and $\delta$, has been experimentally determined.

For the system studied, $\lambda$ has been found to be independent of the cell concentration as well as the operating conditions, provided enough time of contact is given to attain equilibrium. In the present case, equilibrium was approached if the liquid height was kept above $150 \mathrm{~mm}$. An actual foam column may usually have liquid depths of this magnitude. The aerated liquid height is kept above $150 \mathrm{~mm}$ throughout the experiments in order to achieve equilibrium in the bulk section. Experiments with other systems and a wider range of operating conditions will show whether the preceding assumption can be more widely applied.

When foam is formed, it takes the cell mass at a certain rate into the foam section. The cell entry into the foam section comes from two sources: (i) the cells carried by the liquid associated with the bubbles, and (ii) the cells attached to the surface (which are carried into the foam by the surface of the foam bubbles).

As the bubble surface and the broth have been brought into equilibrium in the pool itself, no change in cell concentration occurs either at the surface or in the liquid surrounding it.

Referring to Figure 1, we can write the pertinent balance equations for foam separation:

Cell balance:

$$
\text { Storage: } \begin{aligned}
\frac{d\left(V_{B} C_{B}\right)}{d t}= & Q_{i} C_{B 0}-Q_{0} C_{B}+Q^{\prime} C_{B} \\
& -Q_{1}(1+a \lambda) C_{B}
\end{aligned}
$$

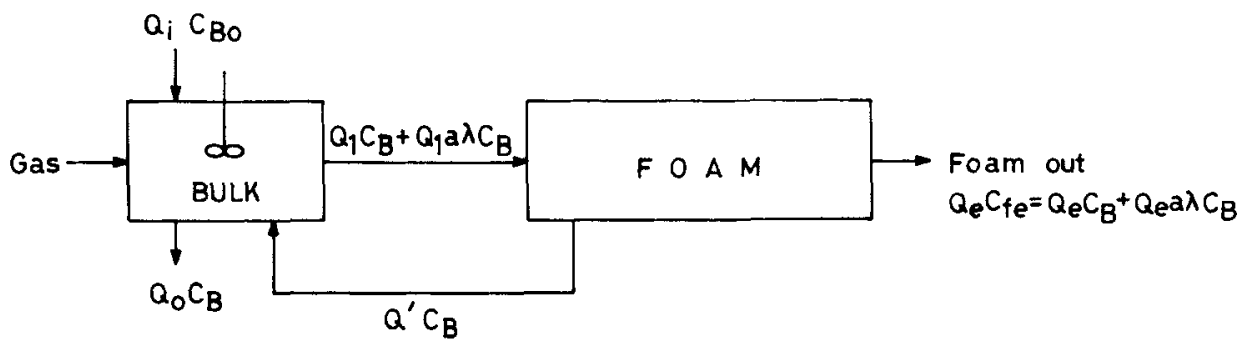

Figure 1. Idealization of foam separation of microbial cells. 
where

$$
\begin{aligned}
& \qquad \begin{array}{l}
C_{f}=(1+a \lambda) C_{B} \\
\text { Foam: }(1+a \lambda) \frac{d}{d t}\left(V_{f} C_{B}\right)= \\
Q_{1}(1+a \lambda) C_{B}-Q^{\prime} C_{B} \\
\\
-Q_{e}(1+a \lambda) C_{B}
\end{array}
\end{aligned}
$$

Liquid balance:

$$
\begin{gathered}
\text { Storage: } \frac{d}{d t} V_{B}=Q_{i}-Q_{0}+Q^{\prime}-Q_{1} \\
\text { Foam: } \frac{d}{d t} V_{f}=Q_{1}-Q^{\prime}-Q_{e}
\end{gathered}
$$

Equations (3)-(6) are the pertinent equations describing the foam separation of cells. The equations have been simplified by the following assumptions and are then solved analytically: (a) The bulk is completely mixed and the cell concentration in it is uniform; (b) since only a batch operation is used for model verification, the terms containing $Q_{i}$ and $Q_{0}$ have been dropped; and (c) the surface viscosity in the PBs is assumed to be infinity. The drainage rate, therefore, will not change with time. As a result, the volume of entrained liquid would be constant, i.e., $d V_{f} / d t=0$ or $V_{f}=V_{f 0}$. Combining Equations (5) and (6) and putting $d V_{f} / d t=0$, we obtain

$$
\frac{d}{d t} V_{B}=-Q_{e}
$$

For a batch operation, Equation (3) becomes

$$
\frac{d}{d t}\left(V_{B} C_{B}\right)=Q^{\prime} C_{B}-Q_{1}(1+a \lambda) C_{B}
$$

Expanding it and using Equation (7), we obtain

$$
V_{B} \frac{d C_{B}}{d t}=Q^{\prime} C_{B}-Q_{1}(1+a \lambda) C_{B}+Q_{e} C_{B}
$$

Expanding Equation (4), we obtain

$$
\begin{aligned}
V_{f}(1+a \lambda) \frac{d C_{B}}{d t}= & Q_{1}(1+a \lambda) C_{B}-Q^{\prime} C_{B} \\
& -Q_{e}(1+a \lambda) C_{B}
\end{aligned}
$$

Adding (9) and (10), we obtain

$$
\left[V_{B}+V_{f}(1+a \lambda)\right] \frac{d C_{B}}{d t}=-Q_{e} a \lambda C_{B}
$$

Before solving Equation (11), $V_{B}$ needs to be expressed in terms of $t$. Furthermore, $V_{f}$ can be put as $V_{f 0}$.

Here $V_{B}$ is a function of time given by equation (7), the solution of which is

$$
V_{B}=Q_{e} \cdot t+\text { const }
$$

To evaluate the constant, an initial condition is required. If the total starting volume was $V_{B 0}$ before foaming, then on foaming a volume $V_{f 0}$ goes to foam, and the initial storage volume is $V_{B 0}-V_{f 0}$.
Using this, equation (12) becomes

$$
V_{B}=\left(V_{B 0}-V_{f 0}\right)-Q_{e} \cdot t
$$

Substituting the values of $V_{B}$ and $V_{f 0}$ in equation (11), we obtain

$$
\frac{d C_{B}}{d t}+\frac{Q_{e} a \lambda}{\left(V_{B 0}+a \lambda V_{f 0}-Q_{e} t\right)}=0
$$

Equation (14) can be solved with the initial condition $(t=$ $0, C_{B}=C_{B 0}$ ):

$$
C_{B}=C_{B 0}\left(1-\frac{Q_{e} t}{V_{B 0}+a \lambda V_{f 0}}\right)^{a \lambda}
$$

When the foam gets formed, the cell concentration in the storage becomes different from that in the original broth and may be obtained from

$$
V_{B 0} C_{B 0}^{\prime}=\left(V_{B 0}-V_{f 0}\right) C_{B 0}+V_{f 0}(1+a \lambda) C_{B 0}
$$

Knowing the values of $V_{B 0}, a, Q_{e}, V_{f 0}$, and $\lambda$, we can predict the cell concentration profile using equation (15). The parameters $V_{f 0}$ and $Q_{e}$ are associated with the foam characteristics. These can be calculated using an existing model $^{9}$ or determined experimentally.

The value of $a$ is obtained from

$$
a=\frac{6.6 Q_{g}}{Q_{e} d_{B}}
$$

where $Q_{g}$ is the gas flow rate and $d_{B}$ the bubble diameter.

The bubble diameter is estimated using the model proposed by Kumar and Kuloor ${ }^{10}$ when a single-capillary distributor is used. When a sintered disc is employed, $d_{B}$ is estimated photographically since no model exists for such a situation.

\section{MATERIALS AND METHODS}

\section{Microorganisms}

In the present work, a microorganism had to be chosen that showed good foaming and separation characteristics and could be used for verification of the model. Both yeasts and bacteria were grown for the initial screening.

The yeasts were routinely maintained on slants of MYGP agar. A freshly prepared 48-h old slant of the culture grown at $30^{\circ} \mathrm{C}$ was used to inoculate $100 \mathrm{~mL}$ sterilized medium. For inoculation, $2 \mathrm{~mL}$ cell suspension made from the slant in sterile water was asceptically transferred into each flask containing the medium. Before inoculation, the media were prepared in flasks plugged with nonabsorbent cotton and sterilized in an autoclave at $15 \mathrm{psig}$ for $20 \mathrm{~min}$ at $121^{\circ} \mathrm{C}$. The inoculated flasks were then placed in a shaker at $200 \mathrm{rpm}$ with a $5-\mathrm{cm}$ throw at $30^{\circ} \mathrm{C}$. After $20 \mathrm{~h}$, the cells were examined under a microscope at 400 magnification and were found to be actively dividing without any vacuolation. They were found to be in exponential growth phase.

The bacteria were routinely maintained on agar slants. Its freshly prepared slant was incubated at $37^{\circ} \mathrm{C}$ for $48 \mathrm{~h}$ 
and used to inoculate $100 \mathrm{~mL}$ sterilized medium. For inoculation only $1.0 \mathrm{~mL}$ cell suspension was used. The rest of the procedure was the same as that used for yeasts except that the temperature of the inoculated flasks was maintained at $37^{\circ} \mathrm{C}$ for $20 \mathrm{~h}$. The bacteria were also examined and were found to be in an actively dividing state. All the slants were prepared by standard method. ${ }^{11-13}$

For the initial screening, the foaming and separation conditions for each microorganism were not individually optimized. Instead, the cultures grown uniformly for $20 \mathrm{~h}$ were employed, and the best available under the conditions were taken up for further study. The various microorganisms tested, the media compositions, and cultivation time are given in Table $\mathrm{I}$.

In order to ensure reproducible foaming characteristics, the various pertinent parameters, e.g., temperature, inoculum size and concentration, slant age, and incubation time, were maintained constant.

For the main work a growth period of $18 \mathrm{~h}$ was employed, though the testing was done for a growth period of $20 \mathrm{~h}$. This was done on observing that $18-\mathrm{h}$ growth yielded marginally better foaming for the yeast selected for detailed study.

\section{Checking Contamination}

The flasks were individually examined for contamination. This was done by examining the live cultures under a microscope at $400 \times$ and $1000 \times$ magnifications. After the examination of live cultures, either a temporary slide (for yeasts) or a smear (for bacteria) was made. The yeasts were stained by lactophenol blue ${ }^{14,15}$ and the bacteria according to Gram's procedure. ${ }^{14,15}$ Contaminated flasks were not included in the pooled material used for the separation experiments.

\section{Assay}

Visual and photometric techniques have been reported by many investigators ${ }^{16-20}$ for quantitative determination of various species of microorganisms. In the present study, percentage of transmittance was used to determine the cell concentration. An UV-Vis Spectrophotometer Graphicord, Shimadzu UV-240, was employed. The percentage transmission at $600 \mathrm{~nm}$ through the microorganism suspension in distilled water was related to the dry-cell concentration through a calibration curve. To analyze a sample, the cells were first separated through centrifuging at $2000 \mathrm{~g}$, and the volume of the supernatant liquid obtained was measured. The cells were washed and resuspended in a volume of mineral-free water equal to that of the supernatant liquid. In all cases, mineral-free water was taken as the reference liquid.

The preceding method was employed during the detailed investigation. During the initial screening of various microorganisms, the concentrations were determined by centrifuging the suspension, washing the cells, and weighing after vacuum drying.

\section{Experimental Setup}

The experimental setup is schematically shown in Figure 2. It consists primarily of the gas supply system and the foam separation column. Dry nitrogen from a cylinder is used to generate foam by sparging it through the culture broth. The flow rate of nitrogen is metered through a calibrated capillary flowmeter.

The exit of the metered nitrogen is connected to a vertical foam separation column, which is made of a $36-\mathrm{mm}$ i.d. glass tube. The foam column is open at the top but has

Table I. Media composition, time cycle, and separation factors.

\begin{tabular}{|c|c|c|c|c|c|c|c|c|c|c|c|c|}
\hline $\begin{array}{l}\text { Run number } \\
\quad \text { and } \\
\text { microorganism }\end{array}$ & Glucose & $\begin{array}{c}\text { Yeast } \\
\text { extract }\end{array}$ & $\begin{array}{l}\text { Malt } \\
\text { extract }\end{array}$ & Peptone & Starch & Sucrose & Agar-agar & Salts & $\begin{array}{l}\text { Cultivation } \\
\mathrm{pH} \text { and } \\
\text { temperature }\end{array}$ & Media & $\begin{array}{c}\text { Cultivation } \\
\text { time, } \mathrm{h}\end{array}$ & $\begin{array}{l}\text { Separation } \\
\text { factor }\end{array}$ \\
\hline $\begin{array}{l}\text { 1. Bacillus } \\
\text { polymyxa }\end{array}$ & 1 & - & - & 1 & - & - & - & $\mathrm{NaCl} 0.5$ & $\begin{array}{l}\mathrm{pH} 7-7.2 \\
31^{\circ} \mathrm{C}\end{array}$ & $\begin{array}{l}\text { Nutrient } \\
\text { broth/Agar }\end{array}$ & 20 & 4 \\
\hline $\begin{array}{l}\text { 2. Aspergillus } \\
\text { niger }\end{array}$ & - & - & - & - & - & 3 & 1.5 & $\begin{array}{l}\mathrm{NaNO}_{3} 0.2, \\
\mathrm{~K}_{2} \mathrm{HPO}_{4} 0.1, \\
\mathrm{MgSO}_{4} 0.05 \\
\mathrm{KCl} 0.05 \\
\mathrm{FeSO}_{4} 0.001\end{array}$ & $\begin{array}{l}\mathrm{pH} 6.0 \\
30^{\circ} \mathrm{C}\end{array}$ & $\begin{array}{l}\text { Czapek's } \\
\text { solution }\end{array}$ & 20 & $\simeq 1$ \\
\hline $\begin{array}{l}\text { 3. Escherichia } \\
\text { coli }\end{array}$ & 1 & - & $\begin{array}{l}\text { Meat } 0.5 \\
\text { extract }\end{array}$ & 0.5 & - & - & - & $\mathrm{NaCl} 0.5$ & $\begin{array}{l}\mathrm{pH} 7.2-7.4 \\
30^{\circ} \mathrm{C}\end{array}$ & $\begin{array}{l}\text { Nutrient } \\
\text { broth }\end{array}$ & 20 & $\approx 1$ \\
\hline $\begin{array}{l}\text { Serratia } \\
\text { marcescems }\end{array}$ & - & - & $\begin{array}{l}\text { Beef } 0.5 \\
\text { extract }\end{array}$ & $\begin{array}{l}1 \text { or beef } \\
\text { extract } 0.1\end{array}$ & - & - & - & - & $\begin{array}{l}\mathrm{pH} 7.2-7.4 \\
30^{\circ} \mathrm{C}\end{array}$ & $\begin{array}{l}\text { Nutrient } \\
\text { broth }\end{array}$ & 20 & 5 \\
\hline $\begin{array}{l}\text { 4. Saccharomyces } \\
\text { carlsbergensis }\end{array}$ & 2 & 0.5 & 0.5 & 1.0 & - & - & - & - & $\begin{array}{l}\mathrm{pH}<7.0, \\
30^{\circ} \mathrm{C}\end{array}$ & MYGP & 20 & $10-90$ \\
\hline $\begin{array}{l}\text { 5. Bacillus } \\
\text { subtilis }\end{array}$ & - & - & - & 1 & 1 & - & - & $\mathrm{NaCl} 1.0$ & $\begin{array}{l}\mathrm{pH} 7.2 \\
30^{\circ} \mathrm{C}\end{array}$ & $\begin{array}{l}\text { Nutrient } \\
\text { broth }\end{array}$ & 20 & $\simeq 1$ \\
\hline
\end{tabular}


1. Foam column

2. Liquid drainage

3. Gas distributor

4. Dummy gas distributor

5. Three way stopcock

6. Flowmeter assembly

7. Inclined manometer
8. Gas cylinder

9. Pressure valve

$10,11,12,13,14$. Outlets

15. Beaker for foam collection

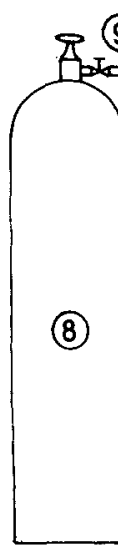

(13)

(13) $\rightarrow 0$

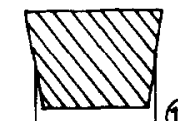

(12)<smiles>CC(=O)NC1CCCCC1</smiles>
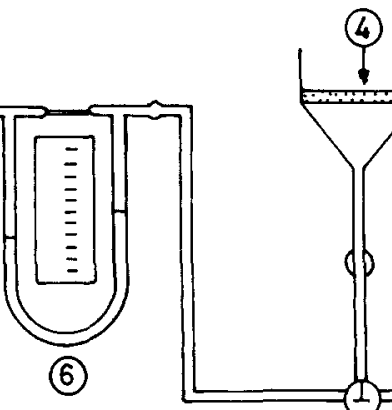

(6)

(5)

Figure 2. Experimental setup.

a gas distributor at the bottom. Two gas distributors have been employed in the present study. For most of the experiments, a single capillary of $0.5 \mathrm{~mm}$ i.d. was employed as a gas distributor. However, to study the effects of variation of bubble diameter on cell separation, a sintered disc of G3 pore size and $25 \mathrm{~mm}$ i.d. was employed for generating smaller bubbles. Just above the gas distributor, an outlet with a stopcock is provided to drain the liquid from the column. There are five more outlets from the column at various heights. These outlets, which are normally plugged, are used to withdraw foam samples and are used to study the effect of foam height on cell separation. A dummy gas distributor (4) is provided to divert the flow of gas while the culture broth is being added to the foam column.

\section{Experimental Procedure}

The foam column is connected as shown in Figure 2, and the gas flow at the desired rate is started through it. When a steady flow is reached, which normally takes about $30 \mathrm{~min}$, the gas flow is diverted through the dummy distributor, and the cell broth is charged to the foam column. The gas is again sparged through the column, and the foam is generated. The foam is withdrawn through the appropriate opening at a predecided height. The foam samples are drawn over known intervals of time. Simultaneously, the broth samples are also withdrawn from the storage section of the foam column. The foam and the broth samples are then analyzed by the methods described earlier. The foam is broken mechanically. Sometimes, a de-emulsifying agent, acetone, was used to break the foam.

\section{Experimental Determination of Separation Parameter $\lambda$}

In the absence of a method for direct evaluation of interfacial cell concentration, an indirect method for evaluating $\lambda$ has been employed. This method uses a shallow foam bed itself for the determination of $\lambda$. A shallow foam bed above a deep liquid pool (>150 mm) was used to generate the interface. The foamate was collected for $1 \mathrm{~min}$, and its cell concentration was determined. The cell concentration in the bulk was found both at the beginning and end of foamate collection, and its average was determined. The value of $\lambda$ was then determined from

$$
\lambda=\frac{1}{a} \frac{C_{f}}{C_{B}}-1
$$

The value of $a$ was obtained from equation (17). A single experiment is enough to find the value of $\lambda$, which then can be used for predicting the influence of various operating and equipment parameters.

\section{Initial Screening of Microorganisms}

A number of microoganisms were first screened to arrive at a specific species to be taken up for detailed investigation. The method of evaluation was to compare the separation ratios for various microoganisms. The separation ratio is defined as the ratio of concentrations of cells in the foamate to that in the broth. In practice, the foam separation experiment is done, and the foamate and the bulk samples are collected. The conditions of experiment are maintained 
constant for various microorganisms. As the bulk concentration undergoes very minor changes during the foam collection, an average of the initial and the final concentration was used. The results obtained and the conditions used are given in Table I. Under the conditions of experiment, $S$. carlsbergensis gave the highest separation ratio and was therefore selected for detailed study. This microorganism is also industrially important.

\section{Reproducibility of Results}

The main measurements of interest in the present investigation are $C_{B} / C_{B 0}$ and $\lambda$. To achieve reproducibility, the conditions of both the cultivation and separation experiments were carefully controlled. It was found that the values of $C_{B} / C_{B 0}$ were reproducible within $\pm 5 \%$ of the mean. In all the experiments the foam samples were collected at intervals of $1 \mathrm{~min}$. The values of $C_{B}$ were however determined by directly drawing samples from the storage section and analyzing them at predecided times. The foam analysis was useful in the calculation of the separation factor as well as for verification of the overall material balance.

To determine the separation factor, the foam sample was collected for 1 min over a shallow foam column, as indicated in the section where determination of $\lambda$ is discussed. It was found that as the foaming progressed, the separation factor varied. This variation was primarily due to the variation of the liquid hold-up in foam with the progress in the separation process. The liquid hold-up in foam varies due to the variation of surface viscosity. In the present investigation, the liquid hold-up was both experimentally determined and calculated from an existing theory using surface viscosity as infinity. The existing model for predicting liquid hold-up was not found good enough. Therefore, in the present work the average value of $Q_{e}$ over the time of the experiment was used.

As a run proceeded, the foam became unstable and foam films started breaking. The run was discontinued at that stage. Further, though the separation factor varied with foaming, the value of $\lambda$, the parameter appearing in the present model, remained constant (Fig. 4).

\section{RESULTS AND DISCUSSION}

\section{Variation of $\lambda$ with Liquid Height and Cell Concentration}

It was indicated during the development of the model that $\lambda$ attains a constant value beyond the storage liquid height of $150 \mathrm{~mm}$. Further, it was assumed to be independent of cell concentration. To ascertain if these assumptions hold, experiments were conducted and $\lambda$ obtained as a function of liquid height in the storage. A typical set of data is presented in Figure 3. The conditions under which these data have been obtained are also mentioned in the figure. Similarly, experiments were conducted under varying operating conditions, and the results confirmed the constancy of $\lambda$ beyond $150 \mathrm{~mm}$ liquid height in the storage section of the foam column. Thus, in all the experiments reported here, the liquid height is maintained above $150 \mathrm{~mm}$.

The value of $\lambda$ was obtained as a function of cell concentration, and the results are reported in Figure 4. The conditions employed in this set of experiments are also mentioned in the figure. While calculating $\lambda$, the required values of $Q_{e}$ were obtained experimentally. It is seen from the figure that $\lambda$ is independent of cell concentration.

As the $\mathrm{pH}$ of the culture would have an influence on $\lambda$, the $\mathrm{pH}$ was maintained at a value of 4.5 during all the experiments conducted to verify the model.

\section{Variation of Cell Concentration in Cell Broth with Time of Operation}

Figure 5 presents the variation of $C_{B} / C_{B 0}$ in the storage as a function of run time for a typical run. The conditions corresponding to this set of experiments are given in the

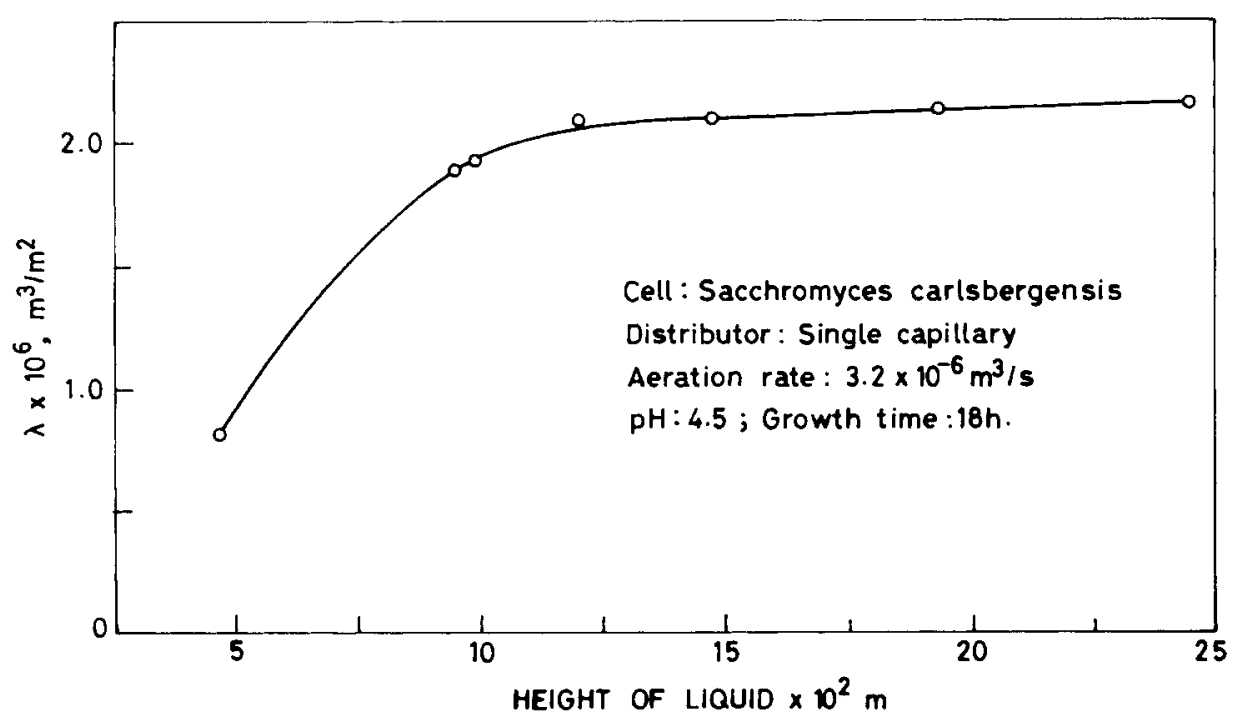

Figure 3. Variation of $\lambda$ with liquid height. 


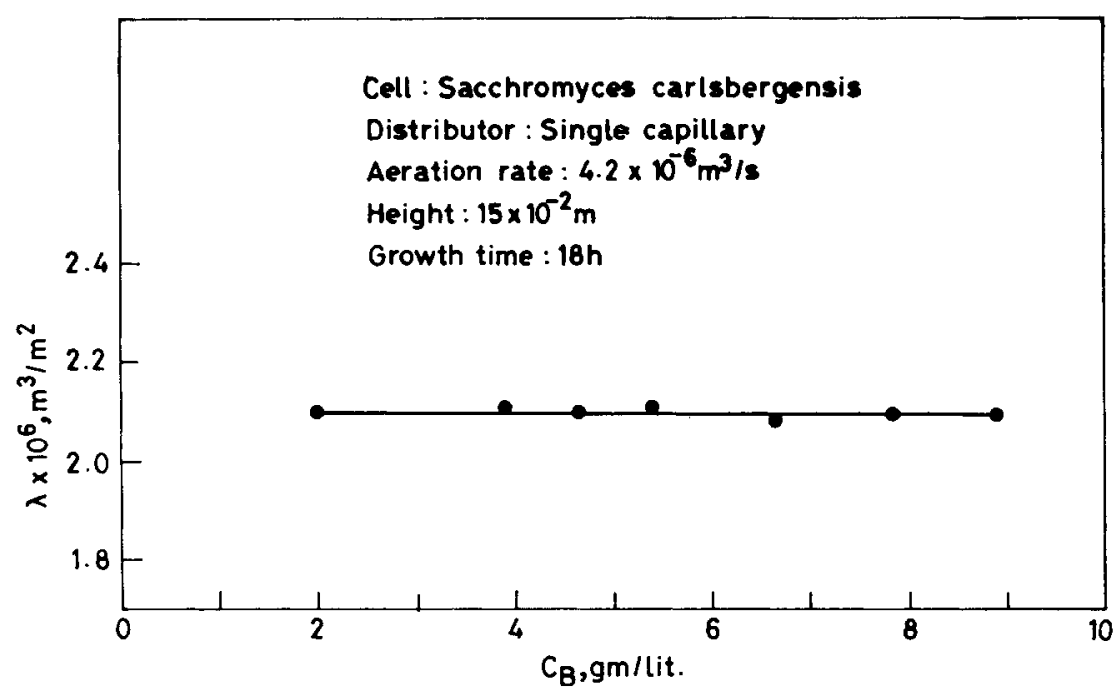

Figure 4. Constancy of $\lambda$ with concentration.

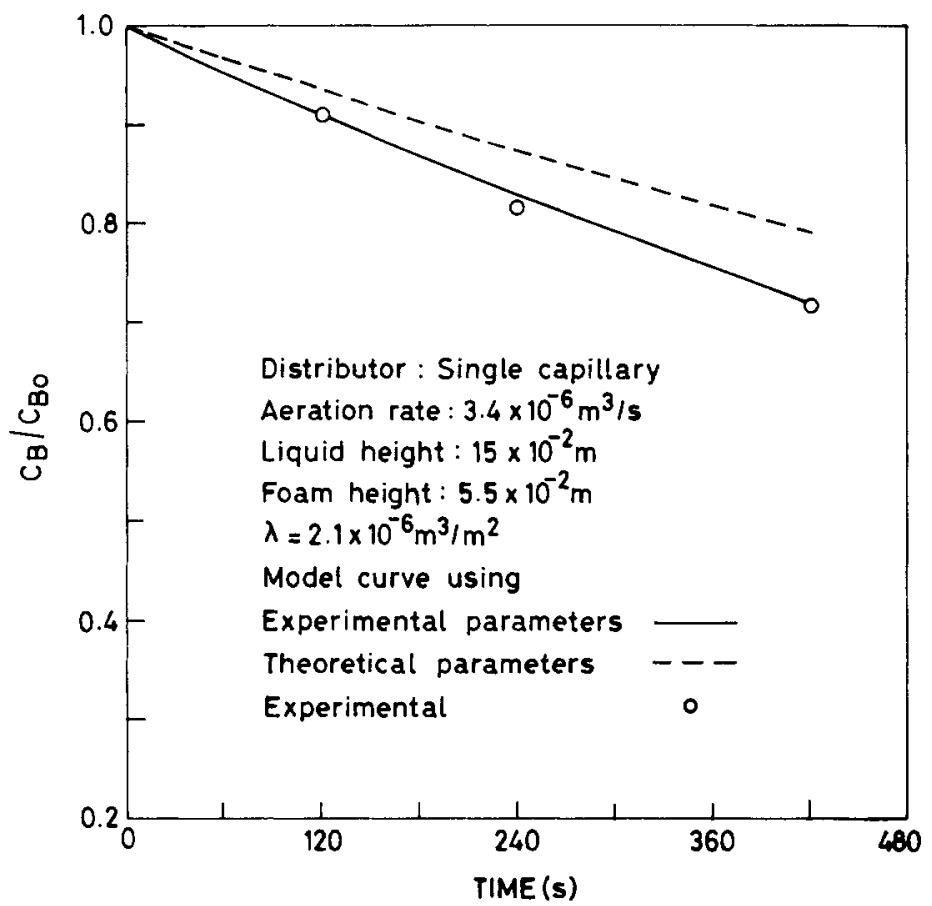

Figure 5. Variation of concentration ratio with time.

figure. As expected, the cell concentration falls as a function of time. In the figure, the points are experimental, and the lines are from model equation (15). The solid line is obtained using experimentally determined values of $Q_{e}$, while the broken line is drawn when theoretical values, obtained from an existing model, ${ }^{9}$ are used. It is seen that the model is able to predict the cell removal from the broth when experimentally determined correct values of $Q_{e}$ are used.

\section{Effect of Bubble Diameter on Cell Removal}

The bubble diameter was varied for the same gas flow rate by changing the gas distributor. To generate small bubbles, a sintered disc was used, whereas for generating larger bubbles, a single capillary was employed. The disc gave an average bubble diameter of $0.4 \mathrm{~mm}$, and the capillary gave bubbles of diameter $3.5 \mathrm{~mm}$, resulting in a variation of bubble size to the extent of one order of magnitude. For both the bubble diameters, the variation of cell concentration with time in the storage section is presented in Figure 6. It is seen that the smaller diameter bubbles remove the cells much faster. This is expected since for the same flow rate, smaller bubbles generate much larger interfacial area. In the case of a single capillary, models for calculating the bubble size already exist, and one such model $^{10}$ was used in the present case (unlike for sintered disc, where the 


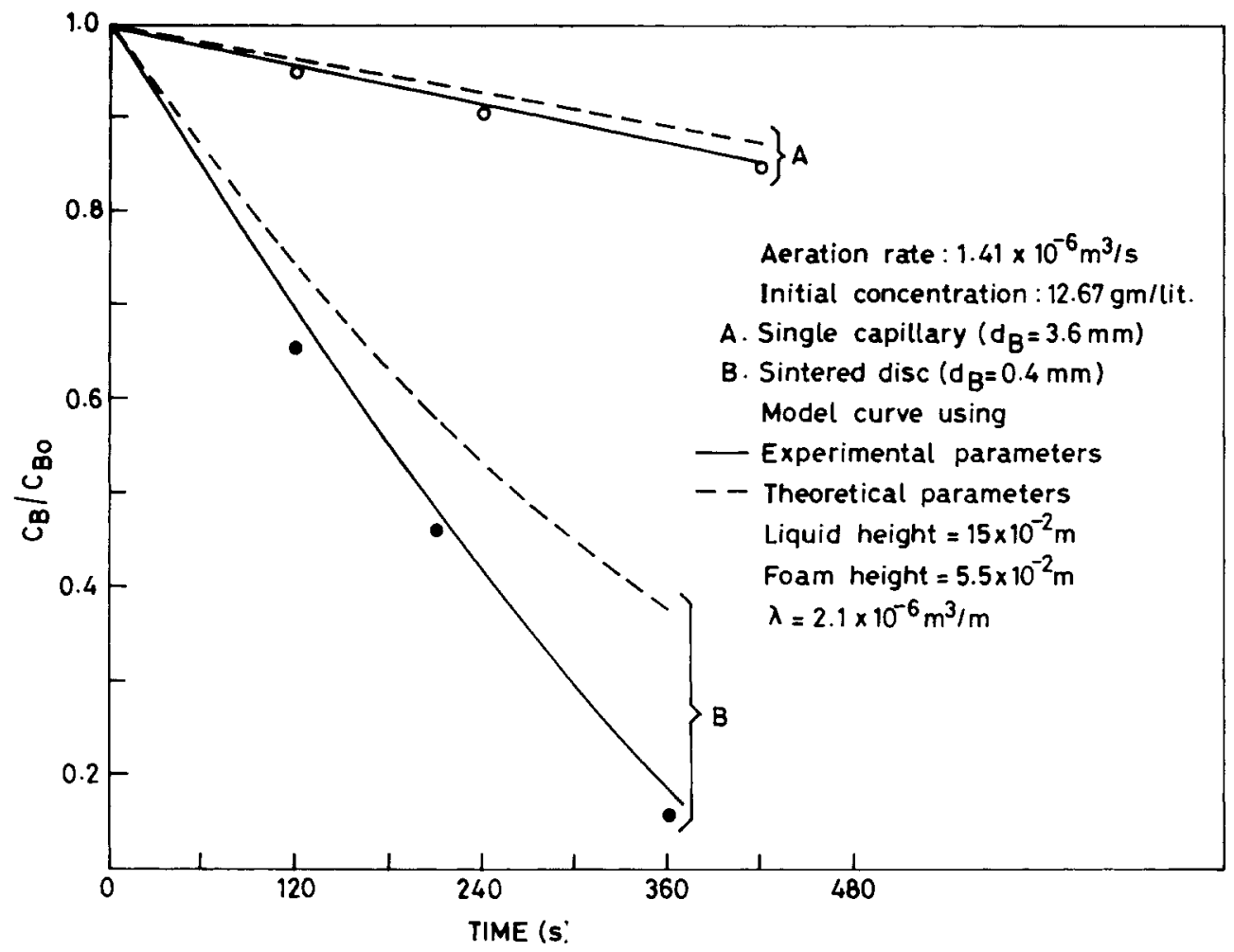

Figure 6. Effect of bubble diameter on separation.

bubble size was estimated by a photographic method). The points in the figure are experimental, and the lines are based on theory. It is seen that the model also predicts the same trends as obtained experimentally for both bubbles sizes. Again, the use of experimentally determined values of $Q_{e}$ gives better predictions than when calculated values are employed.

Although the rate of cell removal is more for the smaller bubbles, the separation factor is higher for larger bubbles. The initial separation factor for smaller bubbles was found to be 2.3 , whereas for larger bubbles it was 19.5 . The theoretically calculated values of separation factors were 3.0 and 19.0, respectively. The large bubbles give dry foam having less liquid hold-up, whereas the smaller bubbles yield higher hold-up of liquid per unit of interfacial area. As the separation factor is a strong function of liquid holdup in the exit foam, it is found that the larger bubbles, having lower liquid hold-up, yield higher separation factor.

\section{Effect of Aeration Rate on Cell Removal}

When aeration rate is increased for a given distributor, both the rate of foamate movement and the bubble size increase simultaneously. The increased bubble size tends to reduce the rate of foamate removal, whereas the increased aeration rate has the reverse effect. To study the effect of aeration rate, use was made of a capillary tube $(0.5 \mathrm{~mm}$ i.d.) as a distributor, as this shows stronger dependence of bubble diameter on gas flow rate. The results presented in Figure 7 correspond to two gas flow rates. The flow rate was varied by a factor of $\sim 3$. It is seen that for a higher flow rate, the rate of cell removal is higher. The values of $C_{B} / C_{B 0}$ as calculated through the model are shown as lines. It is seen that for both flow rates, the model predicts the trends reasonably well.

\section{Effect of Aeration Rate on Separation Factor}

The separation factor is the ratio of cell concentration in foam and bulk. In developing the model, a linear relationship was assumed between the interface and the bulk cell concentration, i.e., $C_{f}=(1+a \cdot \lambda) C_{B}$. Hence $1+a \cdot \lambda$ gives the separation factor. Thus, the separation factor is a function of the interfacial area available per unit volume of liquid at the foam exit. The area of a single foam bubble and foamate rate were changed simultaneously with aeration rate when a single-capillary distributor was used. Experiments were conducted to find the separation factors at different aeration rates, keeping $\mathrm{pH}$, foam height, and initial cell concentration constant. The results are shown in Figure 8 , where the line represents the model, and the points are experimental. The model curve was drawn by estimating $Q_{e}$ by the Desai and $\mathrm{Kumar}^{9}$ model, and bubble size was estimated by the model of Kumar and Kuloor. ${ }^{10}$ It is seen that the model predicts the separation factor quite well. There is a slight deviation at high flow rates where the observed separation factor is lower than the calculated ones. This is due to foam breakage, which occurs at high flow rates and is not taken into account by the model of Desai and Kumar. ${ }^{9}$ 


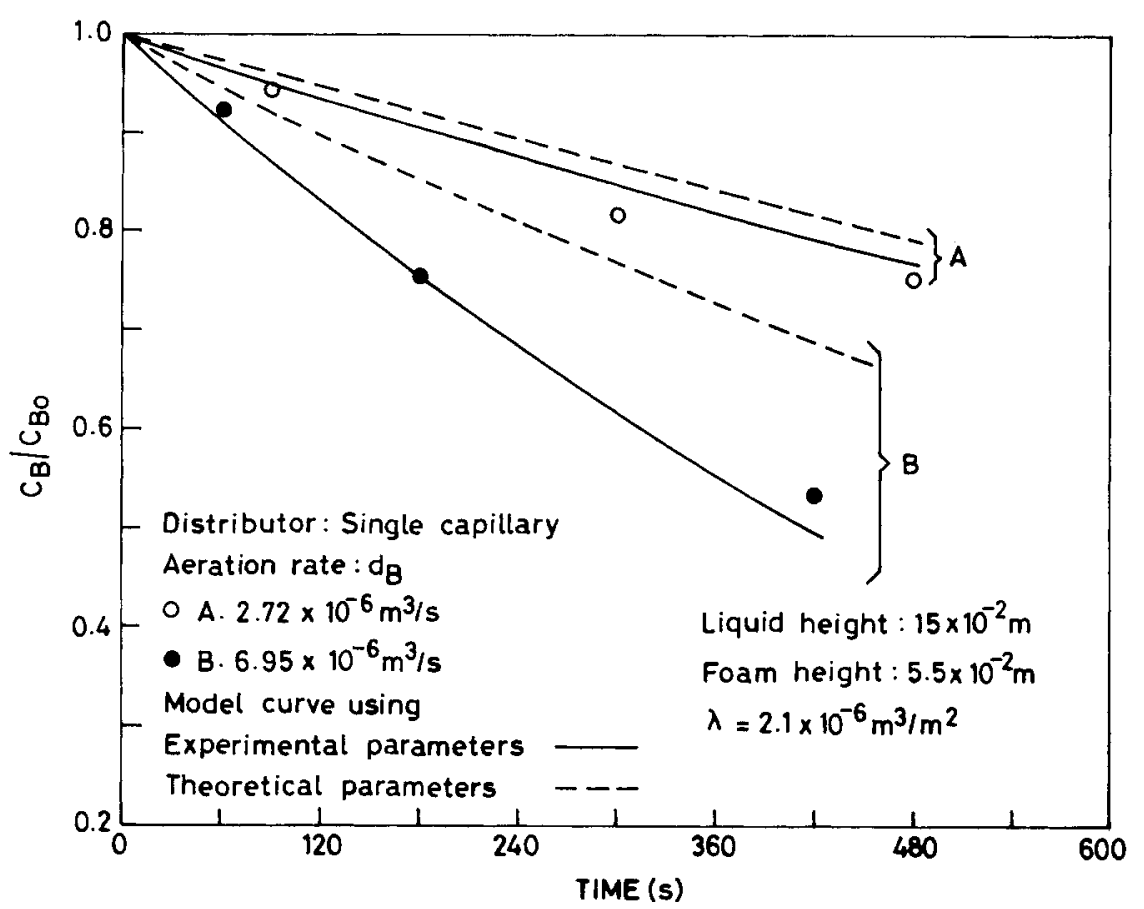

Figure 7. Effect of aeration rate on separation.

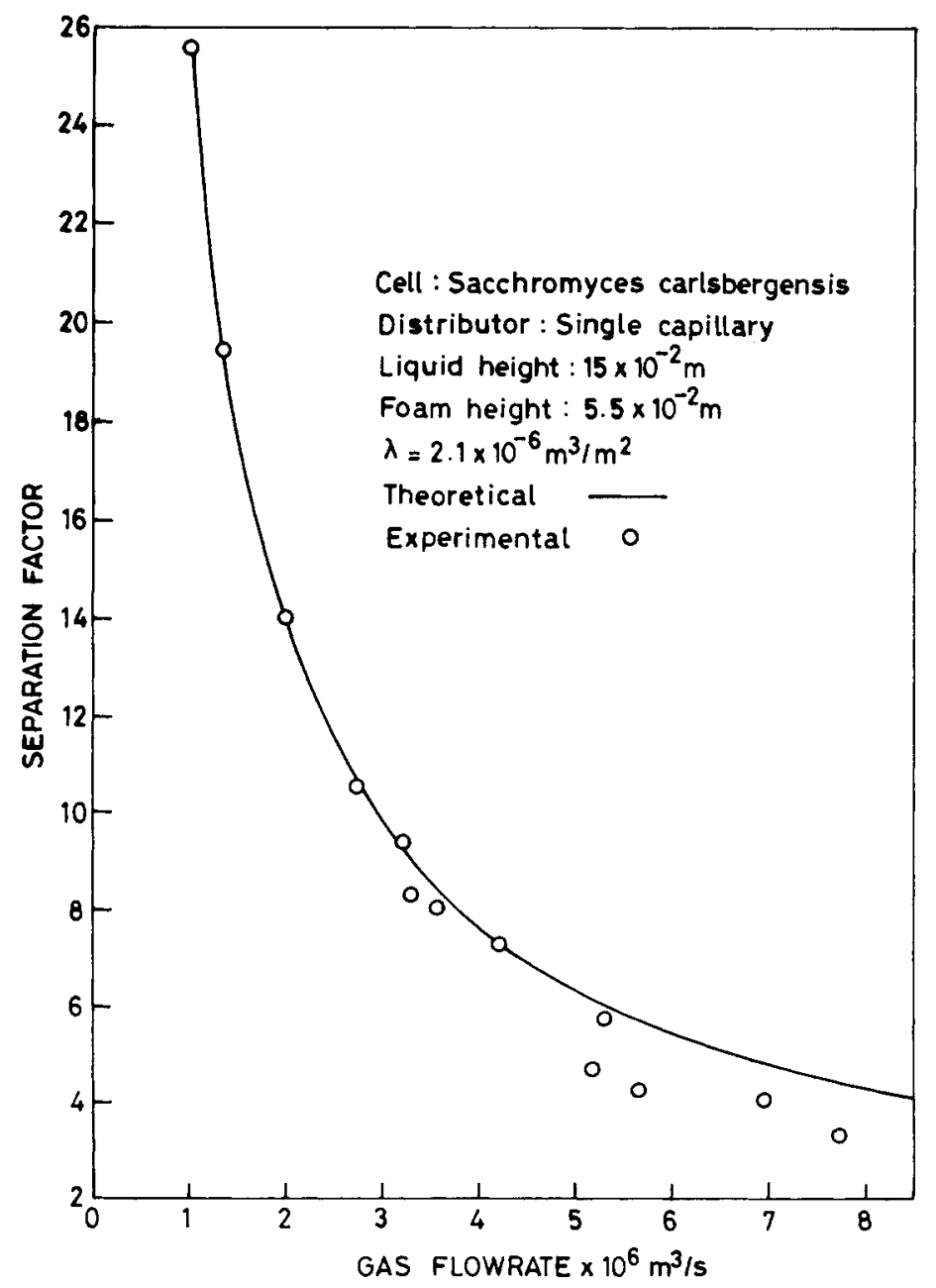

Figure 8. Variation of separation factor with aeration rate. 


\section{NOMENCLATURE}

$a \quad$ interfacial area per unit volume of liquid $\left(\mathrm{m}^{-1}\right)$

$C_{B}$ bulk concentration $\left(\mathrm{g} / \mathrm{m}^{3}\right)$

$C_{f}$ foamate cell concentration $\left(\mathrm{g} / \mathrm{m}^{3}\right)$

$C_{i} \quad$ interface cell concentration $\left(\mathrm{g} / \mathrm{m}^{2}\right)$

$C_{i}^{\prime} \quad$ interface cell concentration $\left(\mathrm{g} / \mathrm{m}^{3}\right)$

$C_{B 0}^{\prime}$ initial cell concentration $\left(\mathrm{g} / \mathrm{m}^{3}\right)$

$C_{B 0}$ cell concentration at $t=0\left(\mathrm{~g} / \mathrm{m}^{3}\right)$

$C_{B} \quad$ average cell concentration $\left(\mathrm{g} / \mathrm{m}^{3}\right)$

$d_{B}$ diameter of bubble (m)

$H$ height of vertical foam section (m)

$K$ proportionality constant defined in eq. (1)

$Q_{1} \quad$ liquid carried by bubbles from pool $\left(\mathrm{m}^{3} / \mathrm{s}\right)$

$Q^{\prime} \quad$ liquid draining from foam to pool $\left(\mathrm{m}^{3} / \mathrm{s}\right)$

$Q_{e}$ rate of liquid overflow in foam $\left(\mathrm{m}^{3} / \mathrm{s}\right)$

$t$ time (s)

$V_{B} \quad$ volume of the bulk $\left(\mathrm{m}^{3}\right)$

$V_{f} \quad$ volume of liquid in foam $\left(\mathrm{m}^{3}\right)$

Greek symbols

$\delta \quad$ cell thickness

$\lambda$ proportionality constant defined by eq. (2) (m)

Subscripts

$B$ bulk

$F \quad$ film

$0 \quad$ value at $t=0$

\section{References}

1. A. J. Rubin, A. E. Cassel, O. D. Henderson, J. Johnson, and J. C. Lamb III, Biotechnol. Bioeng., 8, 135 (1966).
2. A. Thomas and M. A. Winkler, in Topics in Enzyme and Fermentation Biotechnology, A. Wiseman, Ed. (Ellis Horword, Chichester, 1977), pp. 43-71.

3. A. Dognon and A. Dumontet, Cr. Soc. Biol., 135, 884 (1941).

4. W. A. Boyles and R. E. Lincoln, Appl. Microbiol., 6, 327 (1958).

5. M. Ya. Kalyuzhnyi, G. M. Petrushko, and G. R. Novikova, Microbiology, 34, 800 (1965).

6. G. V. Levin, J. R. Clendenning, A. Gibor, and F. D. Bogar, Appl. Microbiol., 10, 169 (1962).

7. G. U. Desmaison and K. Schügerl, Chem. Ind. Tech., 52, 885 (1980).

8. H. Viehweg and K. Schügerl, Eur. J. Appl. Microbiol. Biotechnol., 17, 96 (1983).

9. D. Desai and R. Kumar, Chem. Eng. Sci., 39(11), 1559 (1984).

10. R. Kumar and N. R. Kuloor, in Advances in Chemical Engineering, Vol. 8, T. B. Drew et al., Eds. (Academic, New York, 1970), p. 255.

11. F. W. Beech and R. R. Davenport, in Methods of Microbiology, Vol. 4, (Academic Press, London, 1969), Chapter 5, pp. 153-182.

12. R. C. Codner, in Methods of Microbiology, Vol. 1, (Academic Press, London, 1969), Chapter 11, pp. 427-454.

13. S. R. Lapage, J. E. Sheiton, and T. G. Mitchell, in Methods of Microbiology, (Academic Press, London, 1969) Vol. 3A, Chapter 1, pp. 1-33.

14. D. M. Dring, in Methods of Microbiology, Vol. 4, (Academic Press, London, 1971) Chapter 3, pp. 96-111.

15. J. R. Norris and H. Swain, in Methods of Microbiology, Vol. 5A, (Academic Press, London, 1971) Chapter 2, pp. 105-134.

16. A. J. Rubin, Biotechnol. Bioeng., 10, 89 (1968).

17. R. B. Grieves and S. L. Wang, Biotechnol. Bioeng., 4, 323 (1966).

18. R. B. Grieves and S. L. Wang, Appl. Microbiol., 15, 76 (1966).

19. G. Buchholz, R. Luttermann, W. Zakrzewski, and K. Schügerl, Eur. J. Microbiol. Biotechnol., 11, 89 (1981).

20. U. Stahl, U. Kues, and K. Esser, Eur. J. Appl. Microbiol. Biotechnol., 17, 199 (1983). 